\title{
A COMPARATIVE ANALYSIS OF THEORETICAL AND METHODOLOGICAL FOUNDATIONS OF POLITICAL CULTURE
}

\begin{abstract}
In the modern world, various transformations have an impact on the social and political processes of the society. Even cultural changes somehow depend on these transformations. Therefore, social and political phenomena need new approaches for their study, where the political culture has its proper relevance.

The article explores the theoretical and methodological foundations of a political culture based on the analysis of foreign and Armenian scholars works. The behavioural, psychological, comparative and other approaches, as well as methods of political culture analysis, are examined.

As a result of generalization of theoretical approaches and summarizing the outcomes obtained from a comparative analysis of political culture methodologies, we can define political culture as the aggregate of political ideas, knowledge, traditions and values; as a whole of political participation and behavior models; as a relatively stable link between political consciousness and socialization, between stages and levels of political communication tools and political institutions, which defines the political process and which is expressed through the political discourse.
\end{abstract}

Keywords: theory of political culture, methodological approach, discourse, post-Soviet transformation, social and political processes.

Various transformations that occur in the modern world deeply affect different spheres of public life. Inevitably, these transformations, influenced by the political realities of the Armenian society, create a new requirement to study political phenomena where the political culture plays a very important role. Considering the political culture as a political system's element and as a result of the political process, the analysis of its theoretical and methodological approaches becomes an urgent and necessary scholarly issue. The study of political culture as an element of political system gives an opportunity to reveal its essence and content as well as to characterize political culture as a stable factor in the political process development.

The competition for the formation of new world order has dramatically increased the influence of the venal factor on social processes and particularly on the assessment and classification of the regimes created in the post-Soviet transformation countries. The most efficient way to minimize this impact is the application of new, more accurate approaches and methods of assessment. The problem is more complicated when the subject of the assessment is characterized not only by the political system and its institutions or by the legal norms and structural mechanisms organizing political power, but also by values, behaviour and other ones. In particular, J. 
Linz and A. Stepan (1996) suggest assessing the consolidated democracy in three measurements: behaviour, value, and constitutionalism. The first two measurements are completely, and the constitutionalism is significantly (as it refers not only to the existence of relevant norms in the constitution but also to the attitude of the society towards them) related to the different types of manifestations of the political culture. It is not occasionally that one of the main factors predetermining the nature of new regimes created in post-Soviet countries is the existence of relevant political heritage (culture) in these societies (Linz \& Stepan, 1996).

Consequently, from the point of view of the accuracy of social systems and regimes' assessment, the mechanisms and principles for political culture's assessment are of particular importance. This issue, indeed, needs a political analysis from the perspective to reveal the case of the Republic of Armenia.

This analysis is based on a study and a comprehension of Armenian and foreign researchers works.

From a methodological point of view, it not only allows to reveal the development and structure of political culture, to determine its place and role in society, as well as in the political system, but also it allows to reveal the theoretical, methodological and political aspects of political culture.

The last 25 years are characterized as a period of reforms and modernization in the Republic of Armenia. However, it should be noted that in the Armenian academic literature, this period is characterized as a transformation, which is undergoing a systemic crisis. In their fundamental works on the social and political transformations of a social system, the Armenian researchers like G. Poghosyan, T. Torosyan, A.
Yengoyan $^{1}$ and others referring to this issue, indicate that the process of modernization in Armenia was largely accompanied by certain social and political crises. These crises caused a feeling of some public discontent with the ongoing processes, which, however, did not diminish the desire of society to have a prosperous and stable future.

In this context, the sociologist G. Poghosyan explores the major trends of the modernization of Armenian society based on sociological data analysis. He analyzes the fundamental changes in social structure, in social and political institutions and in social consciousness over the past decade, which are obviously elements of political culture. In his work, the author also considers the issues of the effectiveness of modernization of the Armenian society and emphasizes the social process development prospects in the near future. The author rightly points out that an important theoretical conclusion of the social and philosophical analysis of modernization processes in our reality is the concept of "social backwards", which explains many complex phenomena in post-Soviet societies. First of all, he is talking about such phenomena that are widespread in the post-Soviet space, such as social polarization and deterioration of the social structure, increased emigration and growth in the socially marginal segments of the population (Poghosyan, 2006, p. 354). Thus, the author insists that the modernization in the Armenian society is not a process of reforms at a transitional stage, but rather a process of systemic transformation of society. In contrast to the regulated transitional phase, the transformation is such a change of socium, which initially represents a change in separate basic principles, and the sub-

See more in detail in the following works: Poghosyan, 2006; Torosyan, 2006; Yengoyan, 2011. 
sequent course is out of control and largely has a chaotic and uncontrollable character (Poghosyan, 2006, p. 355).

The transformation process of the social system, trends and their political concepts have been thoroughly analyzed by political scholar $\mathrm{T}$. Torosyan. The author proposes a conceptually new approach to the study of this phenomenon, considering the post-Soviet transformation as a multifunctional, multi-vector, systemic process in its three main dimensions - internal (political), ontological (public consciousness), external (international), the core of which is the choice between the goal of transformation and the way of its implementation based on the principle of civilizational compatibility. In terms of political culture, T. Torosyan (2006) suggests and substantiates the priority to study the role of the political opposition as a prerequisite for consolidated democracy which is an indicator of a full-fledged multi-party system (p. 298).

The concepts of political scientist A. Yengoyan regarding political transformations based on ideological foundations are also interesting. In his works, the author analyzes the key issues concerning ideological basis, strategies and tactics in the process of modernization of the Armenian society. The author's statement that the ideological foundations of modern social and political transformations are designed to adjust democratic principles developed by people to the features of the national political culture is very valuable (Yengoyan, 2011, p. 48). In this context, we can conclude that the artificial implementation of democratization without taking into account national political traditions and ethnic peculiarities cannot ensure an effective modernization of the social and political system. Particularly important is the fact that the author, when studying the ideological bases of social-political transformation in Armenia, distinguishes three stages of the Armenian society's transitional process, which are conditioned by the priorities of one or another ideological system on each other. The first stage involves the period from the declaration of independence to the end of the 20th century and is characterized by the dominant role of liberal values. The second stage lasts for the first decade of the 21st century, when the "second breath" of national values opens, based on which the conservative worldview is activated. And the third stage, characterizing today's Armenian society, is proceeding on the national basis by the coordination and agreement of liberal and conservative ideological systems (Yengoyan, 2011, p. 48). It should be noted that political ideologies also have their place and role in political culture, the systematic study of which gives a clearer picture of the political culture in terms of its ideological features.

In this case, the Russian researcher A. Zdravomislov's (1999) definition of "catchingup modernization", which the author gives to the post-Soviet reality, is very well-turned. It should be noted that in almost all post-Soviet countries the process of modernization was accompanied by certain social and political crises that were inherent not only in public relations but also in various spheres of public life, such as spiritual crisis, crisis of values, which were accompanied by a crisis of public confidence in authorities. In this case, the importance of the value crisis should be emphasized, since its existence predetermines and conditions the essence of the social and political changes taking place in the political culture of the post-Soviet Armenian society. In fact, axiological measurements in political science make it possible to determine in the best way the dynamics of civic positions and transformation of power. And, finally, they let to de- 
termine the degree of appropriation of social and political reforms by society.

The acceptance or rejection of values in politics largely predetermines the formation of peoples civil positions. In this case, power is seen as the most important political value to which the attitude of social groups or individual citizens can be regarded as a conditional factor characterizing political processes. The concept of power, in this case, is closely linked to the state, which one, as a social and political institution, should ensure the organization of its citizens' public life, the realization of national interests and protection of their rights. As the results of a research conducted by the Armenian Sociological Association (ASA) ${ }^{2}$ show, over the past fifteen years, the majority of the Armenian society supports such values as democracy, political and economic pluralism, liberal ideology, etc.

In last years it is noticeable that, in our reality, political and economic modernization is largely accompanied by obvious or invisible conflicts. That's why this process which involves conflicting elements, first of all, requires an axiological approach for the observation of this issue. The transformations taking place in society and in state coincide in time with the individual and group interests, which leads to clashes between their carriers. And the presence of a high level of conflict in society is fraught with many dangers that can manifest themselves in favourable conditions and have serious social and political consequences.

There is also another circumstance that highlights the study of the theoretical and political aspects of political culture. The point is that American researcher K. Fenner (1992) states that the theoretical and axiological study of po-

See more in detail on the official website of the Armenian Sociological Association: www.asa.sci.am. litical culture allows "to define the basic values, knowledge, emotional bonds and loyalty of the citizens to the current system, to define the lack of civic culture values that guarantee stability, create constitutional and psychological conditions, which will lead to the formation of a full civilized or civic culture during political socialization" (p. 70).

The disclosure of the problem's axiological side may clarify the essence of the impact of political culture on the political process. The study of the political process in the frames of political culture makes it possible to take deep roots in the transformations of society and the state since political culture covers all aspects of political life.

It should be noted that in modern academic literature there are about five dozen definitions of political culture, which, among different authors, are mainly based on the differentiation of the whole society, its classes, social groups and individuals as separate elements. Recently, in the process of formation of the multi-party system, civil society and other democratic institutions in Armenia, one can note active studies regarding political parties, social and political movements as elements of political culture. These and other political institutions of our political system, as separate elements, are also studied by Armenian political scientists (G. Keryan, M. Margaryan, A. Markarov, L. Shirinyan, A. Alexanyan, H. Sukiasyan, E. Ordukhanyan ${ }^{3}$ and others). These researchers have analyzed some elements of political culture such as political parties and their typology, the political elite and democratic transitions, the semi-presidential form of governance in post-Soviet era, the main social and political issues in the information society, and the politi-

3 See more in detail in the following works: Keryan, 2002; Margaryan, 2006; Markarov, 2016; Sukiasyan, 2009; Ordukhanyan, 2010; Aleksanyan, 2012; Shirinyan, 2012. 
cal discourse analysis between authorities and opposition. However, the political culture as a separate political science category was studied in the joint research conducted by E. Ordukhanyan and H. Sukiasyan (2012). In this research, the authors observed the political culture in the context of political discourse and information society as new political science categories. In the framework of this research, political consciousness, political behaviour and participation, ideological features of political forces, advantages and disadvantages of e-democracy, etc. were studied. It should be noted that the authors rightly point out the impact of political discourse on political culture and the need for a new informational, political culture formation in Armenia (Ordukhanyan \& Sukiasyan, 2012, pp. 93-94).

As for the studies on political culture in the post-Soviet period, it is important to highlight the Russian researcher Y. Morozova's "Regional Political Culture" work, where the author distinguishes three main approaches to studying political culture based on the analysis of Western political scientists G. Almond, A. Brown, S. Verba, R. Tucker, S. White and others' works.

Behavioural approach, which is based on the methodology of the exact sciences. In this case, the subject of political analysis is the empirical measurement of political behaviour, which includes the sociological sample, interview, mathematical and statistical methods for the scientific analysis of political behaviour.

Subjectivistic approach, which creates additional grounds for studying political culture (memories, fiction, historical and social-historical research). In this case, the past political culture is considered as the main factor fora new political culture formation.

An interpretational approach, which is aimed to redirect the political culture from the political system analysis as a political behaviour to the true and perfect analysis of cultural patterns. In this case, the transfer of political values by symbols is defined as a political link, and the study of that system enables the analyst to explore the political culture in the context of contemporary cultural studies (Morozova, 1998, pp. 40-41).

It should be noted that political culture is deeply studied by Western political scientists, and we will analyze its theoretical and methodological foundations below.

So, one of the best representatives in Western political science who has studied the political culture as a separate political phenomenon is G. Almond. He has tried to make sense of political culture as a concept. G. Almond and S. Verba characterized the political culture as a relatively determined set of social objects and processes that lies at the heart of political actions. Individual orientations, according to the authors, contain several elements: a) cognitive orientation, that is, true or false imagination about political objects and ideas, b) effective orientation, that is, affection, engagement, reaction to political objects, c) estimated orientation, that are judgments and opinions about political objects, which, as a rule, require the use of comparative analysis criteria for political objects and events (Almond \& Verba, 1997, pp. 594-595).

The study of Almond's works is crucial to identify the methodology of political culture research, since its method of comparative analysis of political systems first allows to trace the stages and mechanisms of the formation methodology for political science research, and then identify the features of a comparative analysis of political culture types. In his works, G. Almond was relying on T. Parsons methodology of structural functionalism, and he was observing the political 
sphere of the society as a system that is balanced and interconnected with other social systems. His method of political research gives priority to the cultural-psychological definition of political behaviour. It should be noted that American political scientists G. Almond, as well as S. Verba, S. Beer, A. Ulam, R. Macridis and G. Bradford ${ }^{4}$, are partisans of political culture analysis by behavioural approach. However, the restriction of political culture studies only by psychological factors does not allow to perceive this phenomenon in its collective integrity. Therefore, it can be argued that elaborations made by G. Almond and $\mathrm{S}$. Verba have some vulnerabilities in terms of the differentiation of political culture elements. For example, ignoring political behaviour patterns and models adopted and appropriated by society in the process of political culture analysis narrows the concept of political culture. And American political scientists are often idealizing the Anglo-Saxon political culture by presenting it as a universal civilization criterion. However, it can definitely be argued that every nation, people or civilization has a historically and traditionally formed culture. The neglect of its peculiarities and the forced blind input of foreign elements cannot guarantee stability for the political system being under the formation of a new political culture.

G. Almond and S. Verba describe the US political culture of the 1950 s as homogenous, the basis of which is freedom. However, later studies on US political culture conducted in the 1970s by D. Elazar (1972), reveal the unilateral nature of the above-mentioned statement, linking it with the powerful migration flows to the US and the resulting new political subcultures.

4 See more in detail in the following works: Almond \& Verba, 1992; Beer \& Ulam, 1958; Macridis, 1961; Bradford, 2000.
Another political scientist P. Sharan (1992 $\left.{ }^{\mathrm{a}}\right)$ as a supporter of the psychological approach, when studying political culture, gives preference to the subjective orientations of people, emphasizing that political culture in itself includes the main features of the political system and psychological standards (p. 152). Being one of the political system elements, the political culture predetermines its functioning. It means it serves as a factor in the development and orientation of the political process.

A Polish political scientist E. Vyatr defines political culture as integrity of attitudes, values, and behavioural models that relate to the relationship between authorities and citizens. In fact, in his works the Polish researcher provides a more comprehensive and general definition of the political culture structure, including the following components: a) knowledge of politics, familiarity with facts and interest in them, b) assessment of political phenomena, c) the emotional aspect of political positions such as love of country, hatred of the enemy, d) types of political behavior in a given society that determine how to act in political life (Vyatr, 1979, pp. 259-260).

The American researcher S. Lipset (1972) defines political culture as a whole of rituals, which is to preserve the legitimacy of various democratic operations (p. 203). It is impossible to study political culture from the material point of view and to reveal its influence on political process without studying foreign authors, since the elements of national political culture are analyzed from the point of view of specific positions of national representatives in relation to political objects (Almond \& Verba, 1963, p. 13). The answer to this question is exhaustive. G. Almond and S. Verba (1997) note that their definitions and classifications on the types of political orientations are based on T. Parsons and E. Schiller's 
approach. "The orientations relate to appropriated aspects of social objects and relationships" (p. 595). American political scientist L. Dittmer points that with the help of political culture study, it becomes possible to characterize the national character and the impact of collective historical experience on national identity ${ }^{5}$.

In foreign political science, the problem of personal political culture plays an important role. In some cases, the study of this issue is carried out by revealing the essence of political socialization. For example, Indian political scientist P. Sharan $\left(1992^{\mathrm{b}}\right)$ interprets personal political culture as a subjective response to a political system (p. 46). On the one hand, P. Sharan perceives the political socialization as political views and values imposed on people. On the other hand, he perceives it as a situation when a person creates himself his views on political reality, which shapes his attitude towards individuals, politics, events and demands (Sharan, 1992 ${ }^{\mathrm{b}}$, p. 6).

The main function of political socialization is to ensure the ability for the citizens to interact with the political system. The consideration of political socialization issue is important from a scientific and practical point of views since no political institution can be viable unless a person accepts it as part of a social mechanism and shows no interest in it. From the methodological aspect, the views of P. Berger and T. Lukman are important for us, because they view socialization as a social structuration of reality, distinguishing two main forms - primary and secondary. They argue that primary socialization is crucial for the development of an individual and society, the main element of which is the family. And sec-

5 See more in detail in Politicheskaya kul'tura $v$ ramkakh politicheskogo menedzhmenta (Political Culture in the Framework of Political Management, in Russian). Retrieved September 26, 2018 from: http://www.char.ru/348/298158.htm. ondary socialization is a special role-based acquisition when roles are directly or indirectly connected with the division of labour (Berger \& Lukman, 1995, pp. 219-225).

In Western political science, the politicization is usually considered as induction of political culture, the result of which is the summation of positions, information, values and attitudes about the political system. In this case, the focus is made on the fact that politicization includes not only intentional inspiration of political knowledge and values through educational factors, but also it includes the political education in general ("International Encyclopedia of Social Science," 1968, p. 551). It should be noted that the politicization can both promote and inhibit the conservation of the political system's equilibrium. It functions as a factor that affects the stability of the political system, which is possible in the case of a targeted impact on the political culture. The projection of these theoretical positions on the contemporary Armenian society demonstrates that the excessive politicization of society, undoubtedly, has both positive and negative consequences the political system under appropriate circumstances. As an example, election and postelection processes, mass protests and other events can be cited.

The study of the views of foreign authors on political culture makes it possible to clearly distinguish their positions on the typology of political culture. For example, G. Almond and S. Verba (1965) distinguish patriarchal, subjective and participatory forms of political culture, emphasizing civic culture which is defined as "culture of loyal participation" (p. 54). The basis of this typology is a change in the political orientations of the subject to political institutions, the dynamics of its political activity, which are developed during historical development. As for Polish po- 
litical scientist E. Vyatr (1979), based on the relationship between political cultures and political systems, he suggests the following typology of political culture: traditional, bourgeois-democratic and social-democratic (p. 148).

The above-mentioned typology of political culture cannot be universal. It should be admitted that G. Almond, S. Verba, E. Vyatr and others have conducted their research in precise historical situations and concrete countries which have their own peculiarities. In their works, the most valuable is the methodology of scientific research, thanks to which they realized the typification of political culture. It should be noted that the methods and analytical approaches for political culture research developed by these authors are widely and effectively used even today by other researchers. The key element to define the types of political culture is the axiological component, which dominates in individual and societal consciousness. In this case, it is about the axiological definition of political culture typology.

We have to notice that the theories and classifications presented in these works explain only some of the characteristics or peculiarities of political culture relevant to specific societies. In this regard, the work of S. Kiss (2014) is very important for us, because there the author proposes to summarize various approaches to the measurement of the political culture in the context of the theory of culture, taking into account also the changes emerged in historical and political realities (p. 1). Language is the only common element in all cultures. And in the case of political culture, this is about political discourse. In other words, the discourse is an element that exists in any political reality. So it also gives an opportunity to examine, assess, and measure the poli- tical culture.

Studying M. Foucault's concept of "power and knowledge" on culture, V. Kravchenko mentions that political culture is interpreted as a normative attitude to politics, which people perceive as an independent assumption of something when the political culture is not that in fact, because no idea or notion cannot be considered a priori. The central role in this concept plays political discourse. Each discourse is structured in accordance with certain rules that limit the choice of possible discourse expressions. This is not an unwilling mixture of expressions, but a well-defined and limited semantic space. Thus, political culture as a set of cultural codes cannot be independent of what we are talking about and thinking about. It varies to the extent that our thoughts and words are changing. The political culture cannot be changed spontaneously or by anyone's will. It functions as a result of collective use of appropriate words and concepts in the whole of various discourses. In this case, the participants in political activities are not considered as its subjects, but agents (Kravchenko, 2004, pp. 135-153). From the point of view of this approach, it can be noted that political discourse directly reflects the political culture of society, since changes in political culture are manifested in political discourse. Therefore, the political discourse can be considered as a factor to assess the political culture.

The culture develops and exists as a result of communication, which is a two-way process. In order for someone to respond to your ideas, you need some means of communication that will be available to the respondent. That is some kind of gesture, voice, sign, and so on. And the language through which communication takes 
place plays a very special role in the culture (Strezhenova, 2002, p. 142). Consequently, the political culture is developed and exists as a result of political communication, where the keyrole is played by political discourse.

\section{Conclusion}

A comparative analysis of the theoretical and methodological foundations of political culture shows that in recent years the theory of political culture has been enriched with new scientific elaborations reflecting the features of political time and societies based on practical studies of the political process. The theory of political culture has been enriched by various scientific researches, especially on political subcultures, carried out by representatives of western and eastern political schools. Over time, the methodology for political culture research has also been expanded. The newly developed methods have largely derived from the objectives set out in precise research, as political culture, being the most important factor in the political process, is also changing over time, making dominant any model of the political culture in any society.

And finally, comparing the above mentioned theoretical approaches of political culture and summarizing the results obtained from a comparative analysis of political culture methodologies, we can define political culture as the aggregate of political ideas, knowledge, traditions and values; as a whole of political participation and behavior models; as a relatively stable link between political consciousness and socialization, between stages and levels of political communication tools and political institutions, which defines the political process and which is expressed through the political discourse.

\section{REFERENCES}

Aleksanyan, A., (2012). The Influence of Social Partnership on Regime Democratization in Armenia. "Banber"- Bulletin of Yerevan University, 138.5, 4-23.

Almond, G., \& Verba, S. (1963). The Civic Culture. Political Attitudes and Democracy in Five Nations. Princeton: Princeton University Press.

Almond, G., \& Verba, S. (1992). Grazhdanskaya kul'tura i stabil'nost demokratii (Civic Culture and Sustainability of Democracy, in Russian). Polis journal, 4,122-135.

Almond, G., \& Verba, S. (1997). Grazhdanskaya kul'tura. Politicheskie ustanovki i demokratii pyati nacii (Civic Culture. Political Attitudes and Democracy in Five Nations, in Russian). In G. Semigin (Ed.), Ontology of World Political Thought. Issue 2. Foreign Political Thought in the XX Century (pp. 594595). Moscow: Misl.

Beer, S., \& Ulam, A., (1958). Patterns of Government. New York: Random House.

Berger, P., \& Lukman, T. (1995). Social'noe konstruirovanie real'nosti (The Social Construction of Reality, in Russian). Moscow: Medium.

Bradford, G., (2000). The Politics of Culture: Policy Perspectives for Individuals, Institutions, and Communities. New York: New Press.

Elazar, D., (1972). American Federalism: A View from the States. New York: Crowell.

Fenner, K, (1992). Political Culture. In V. Pus'ko (Ed.), Political Science: Brief Thematic 
Dictionary. The issue I (pp. 6-18).

Moscow: PMB RAU.

International Encyclopedia of Social Science. (1968). Vol. 13. New York: Free Press and MacMillan.

Keryan, G., (2002). Qaghaqakan kusakcut'yunneri tipabanut 'yuny' (The Typology of Political Parties, in Armenian). Yerevan: Van Aryan.

Kiss, S., (2014). Measuring Political Culture and Values in Comparative Perspective: Operationalizing Group-Grid Cultural Theory, European Consortium for Political Research. Montreal. Retrieved September 26, 2018, from:

http://ecpr.eu/Events/PanelDetails.aspx ?PanelID=4173\&EventID=94

Kravchenko, V., (2004). Politicheskaya kul'tura kak otrazhenie politiko-kommunikativnoi real'nosti obshchestva (The Political Culture as a Reflection of Society's Political and Communicative Reality, in Russian). In M. Vasilyuk (Ed.), Actual Problems of Communication Theory (pp. 135-153). Saint Petersburg: SPB.

Linz, J., \& Stepan, A., (1996). Problems of Democratic Transition and Consolidation: Southern Europe, South America, and Post-Communist Europe. Baltimore and London: JHU Press.

Lipset, S., (1972). Politicheskaya sociologiya (Political Sociology, in Russian). In G. Osipov (Ed.), American Sociology: Perspectives, Problems, Methods (pp. 203-219). Moscow: Progress.

Macridis, R., (1961). Interest Groups in Comparative Analysis. Journal of Politics, 23(1), 25-45.

Margaryan, M. (2006). Qaghaqakan y'ntranin \& jhoghovrdavarakan ancman himnakhndirnery Hayastani Hanrapetutyunum (Political Elite and Problems of Democratic Transition in the Republic of Armenia, in Armenian). Yerevan: PetakanTsarayogh.

Markarov, A. (2016). Semi-presidentialism in Armenia. In R. Elgie, S. Moestrup (Eds.), Semi-Presidentialism in the Caucasus and Central Asia (pp. 6190). London: Palgrave Macmillan.

Morozova, E. (1998). Regional'naya politicheskaya kul'tura (Regional Political Culture, in Russian) (A. Zinoviev, Ed.). Krasnodar: Kuban University Publication.

Ordukhanyan, E, (2010). Ishxanut'yan \& y'nddimut'yan qaghaqakan xosuyt'i verluc'ut'yun (The Discourse Analysis of Power and Opposition, in Armenian). Yerevan: Limush.

Ordukhanyan, E., \& Sukiasyan, H., (2012). Qaghaqakan mshakuyt'i arandznahatkut'yunnery' Hayastanum (The Peculiarities of Political Culture in Armenia, in Armenian). Yerevan: Lusabac.

Poghosyan, G., (2006). Hay hasarakut'yuny' 21rd daraskzbin (The Armenian Society at the Beginning of 21th Century, in Armenian). Yerevan: Lusabac.

Politicheskaya kul'tura $v$ ramkakh politicheskogo menedzhmenta (Political Culture in the Framework of Political Management, in Rusian). Retrieved September 26, 2018 from: http://www.char.ru/348/298158.htm.

Sharan, P. (1992 ). Politicheskaya sistema (Political System, in Russian). In M. Dogan (Ed.), Political Science Yesterday and Today, Issue 4 (pp. 6-12). Moscow: 
RAU.

Sharan, P. (1992 $)$. Sravnitel'naya politologiya (Comparative Political Science, in Russian). (Parts 1, 2). Moscow.

Shirinyan, L. (2012). Hayastani qaghaqakrt'akan inqnut'yuny' Hantingtoni hipot'ezi vospnyakum (The Civilization Identity of Armenia in the Lens of Huntington's Hypothesis, in Armenian). Yerevan: Bavigh.

Strezhenova, M., (2002). Politicheskaya kul'tura v razlichnikh interpretaciyakh: analiz special'nogo ponyatiya (Political Culture in Different Interpretations: The Analysis of a Special Notion, in Russian). Social Sciences and Modernity, 5, 141-155.

Sukiasyan, H. (2009). Teghekatvakan hasarakut'yan dzevavorman social-qaghaqakan himnaxndirnery' (Social and Political Problems of Information Society
Formation, in Armenian). Yerevan: Sarvard.

Torosyan, T., (2006). Hasarakakan hamakargi hetxorhrdayin transformacia (Post-Soviet Transformation of Social System, in Armenian). Yerevan: NAS RA Publication.

Vyatr, E. (1979). Sotsiologiya politicheskikh otnoshenii (Sociology of Political Relations, in Russian). (F. Burlatski, Trans. and Ed.). Moscow: Progress.

Yengoyan, A., (2011). Ideologicheskie osnovi sotsial'no-politicheskikh transformacii $v$ postsovetskoi Armenii (Ideological Foundations of Social and Political Transformations in Post-Soviet Armenia, in Russian). Yerevan: RAU Publication.

Zdravomislov, A., (1999). Sociology of Russian Crisis. Articles and Reports of the 90's. Moscow: Nauka. 